\title{
Foreign Market Entry Strategies
}

\author{
Kenneth Shaw \\ State University of New York, Oswego, USA
}

\begin{abstract}
This paper discusses issues surrounding foreign market entry. Initially, the paper attempts to determine why and how a company makes a decision to enter a foreign market. Then there is a discussion of the timing and scale of entry which must be considered. Next is a discussion of government resources and organizations that can assist in entry decisions. Modes of entry are then examined followed by three case studies in foreign market entry.

Keywords: foreign market entry, timing, scale, government resources, international business, US Export Import Bank
\end{abstract}

\section{Introduction}

In recent years, foreign market entry has become increasingly popular. Entry decisions are also gaining attention from researchers of international business.

Entering into a foreign market can potentially offer a firm many benefits in the global marketing area. The primary obstacle encountered by a multi-national enterprise when entering a foreign market is the selection of an entry mode. There are many decisions that need to be made when choosing to enter a foreign market. These decisions include which foreign markets to enter, when to enter them, on what scale, and the choice of entry mode. All comprehensive foreign market entry strategies offer unique benefits and costs and no two specific firm's entry strategies and results are the same. This review will look at various cases of foreign market expansion and seek to find if there is a best entry strategy.

When deciding which foreign markets to enter, the choice is based upon an analysis of a nation's long-run profit potential. Not all nations can offer the same profit potential to a firm and the potential is based on factors such as the economic and political environment of the country. The economic attractiveness of a country is comprised of the size and demographics of the market, the present and future wealth of the country, the living standards, and potential economic growth. A country's attractiveness can also depend on the benefits, costs, and risks associated with doing business in that country. Costs and risks involved with conducting business in a foreign country are generally lower in countries that are economically advanced and politically stable which have a free market system with little inflation or private sector debt. However, the potential for growth may be greater in an undeveloped country. Lastly, the value an international business can create in a foreign market is another important factor. This is dependent on how suitable the product offering would be to that market and the nature of competition in the country. Entry in a foreign market will be successful, if the international business can offer the market a product that is not readily available and satisfies an unmet need. That value will

Kenneth Shaw, Ph.D., associate professor, Department of Management and Marketing, State University of New York at Oswego, USA.

Correspondence concerning this article should be addressed to Kenneth Shaw, 312 Rich Hall Oswego, NY, 13126, USA. E-mail: shaw@oswego.edu. 
offer the business the opportunity to charge higher prices and rapidly increase sales. Taking all of these factors into consideration, a firm should then rank countries based on their long-run profit potential and attractiveness (Porter, 1980).

\section{Timing and Scale}

After a firm has chosen an attractive market, the next decision to be made is the timing of entry. Entry is considered early, when an international business enters the market prior to other foreign firms and late when it enters after other firms have already established themselves in the market. Entering the market early brings first mover advantages that include the opportunity to establish a strong brand name, acquire demand from the market, increase sales volume, and create switching costs that attach a customer to a given product or service. However, entering the market early can bring pioneering costs that a firm that enters the market later may be able to avoid. Pioneering costs include the costs of promoting and establishing the product. The probability of a firm surviving in a market increases, if they enter after several other firms have already established the market. Government regulations can also put an early entrant at a disadvantage, because laws can hinder the value of the early entrant's investment (Hill, 2013).

The next decision that needs to be made is the scale of entry and strategic commitments. Significant assets and resources are needed for a large scale foreign market entry, which commits a firm to the market. Strategic commitments alter the competitive playing field for other firms and produce various changes and inflexibility for the firm. Large scale market entry implies rapid entry and offers the first mover advantages, such as demand acquisition, scale economies, and switching costs. An entry on a smaller scale allows the firm to build themselves up gradually while becoming better acquainted with the market and limiting exposure to the market. Small scale market entry can also make it difficult for the firm to increase market share, because of their lack of commitment to the market. The small scale entrant reduces potential risk but also misses out on the opportunity for first mover advantages (Porter, 1980).

Taking all of these considerations into mind, there are not right or wrong decisions for a firm to make. Each series of decisions offers unique rewards and benefits and costs and risks. Entry strategies that are associated with high risk include entering into a developing nation and entering on a large scale. Such entry strategies offer many benefits as well. Entering on a large scale can offer first mover advantage and long-run potential in the market.

\section{Resources}

There are many resources available through governments, non-governmental organizations, and multinationals which facilitate a solid framework for entering any foreign market. Most of these resources are free or have very low costs. Some examples of these resources include the United States Commercial Service, which administers market reports, local partner searches, trade missions, and support for U.S. firms interested in pursuing exporting or entering target markets. This service operates in the U.S. and 100 other foreign countries. Another example is the Overseas Private Investment Corporation, an agency of the federal government that provides political risk insurance and project financing for projects that seek direct investment by U.S. firms. The U.S. Export Import Bank is an export credit agency of the federal government that provides insurance and financing for various projects that involve direct investment by U.S. firms across various industries. The U.S. Trade Development Agency offers grants for overseas projects that involve U.S. exports. 
The Overseas Security Advisory Council aims to help U.S. businesses better protect their foreign operations, especially in countries with unstable conditions. The American Chamber of Commerce offers advocacy and support for U.S. firms in various foreign nations. A last example is The Princeton Council on World Affairs which offers education, information, and strategic business development services for firms looking to expand in foreign markets (Gordin, 2011).

Once a firm decides how they are going to enter the market, the next decision to make is what mode of entry they are going to pursue. There are six different modes of foreign entry: exporting, turn-key projects, licensing, franchising, establishing a joint venture with a host country firm, or establishing a wholly owned subsidiary in the host country. Each mode of foreign market entry offers various advantages and disadvantages (Root, 1987).

In a case that examined 20 Romanian companies and their strategy of foreign market penetration, various conclusions were made. The objectives of this study were to identify a Romanian exporting company profile, to highlight the organization of marketing activities for exporting enterprises, to identify the areas of activity for exporting enterprises, to identify the main export markets of the Romanian exporters, to identify the international experience of the Romanian exporting companies, and to identify the type of strategy used for entry into foreign markets by exporting Romanian enterprises and testing the model for grouping strategies on the proposed foreign market penetration (Harangus \& Duda, 2009). The main export markets of the surveyed companies were those of the European Union (EU), with over 88\% of exports in 2007 being directed to markets in the EU. The most targeted foreign markets were, in order of relevance, Italy, Germany, France, Hungary, Bulgaria, Austria, and also the United States (Harangus \& Duda, 2009). The results of the research concluded that approximately $60 \%$ of companies with high turnover used forms of direct export or had representation abroad. High turnover is defined by the study as having over 51 billion lei in capital (lei being the plural of leu, Romania's currency). It was also concluded that $50 \%$ of companies with turnover less than 50 billion lei preferred cooperating with a foreign intermediary for their products to enter the foreign markets. This study also concluded that the most common strategy of foreign market entry for Romanian exporters in the developed markets of the EU or the U.S. was direct exporting, while the emerging markets of Central and Eastern Europe or Asia used the more cautious approach of a local intermediary in most cases.

Another case looked at Tesco, the largest grocery store chain in the United Kingdom that owns a $25 \%$ share of the British market. By the early 1990s, their business was already booming and the company was generating a large amount of free cash flow. Senior management had to decide what to do with the excess money they were earning and one strategy they agreed upon was foreign expansion. They decided that they were interested in entering emerging markets in Eastern Europe or Asia. These emerging markets offered them one limited competitor and strong potential for growth. Their first endeavor was into a state-owned grocery chain with 43 locations in Hungary in 1994, when Tesco acquired a 14\% market share. Then in 1995 they acquired 31 stores in Poland. In 1996, they acquired 13 more stores in the Czech Republic and Slovakia (Hill, 2013).

Tesco began expanding into Asia in 1998 in Thailand, when they purchased 75\% of Lotus, a local food retailer. Then they expanded into South Korea in 1999, when they partnered with Samsung. They then entered into Taiwan in 2000, Malaysia in 2002, and China in 2004. They were initially attracted to the Chinese market because of its large size and rapid growth. They ultimately settled on a 50-50 joint venture with Hymall, a hypermarket chain. In 2007, Tesco entered the U.S. grocery market. By 2010, they had generated over 19 
billion euros outside the United Kingdom. They believe that their success was based upon devoting a large amount of attention to transferring its core capabilities in retailing to the new acquisitions instead of sending expatriates, their partnering strategy with Asia, and their focus on markets with good growth potential (Hill, 2013).

Another case involves the 2004 strategic alliance of Cisco Systems and Fujitsu, a Japanese computer, electronics and telecommunications equipment company. By entering into this alliance with Fujitsu, Cisco believes that it can accomplish a number of different goals. First, both firms are pooling their research and development efforts that enable them to share technology and produce new products more easily. Second, by combining Cisco's cutting edge technology and Fujitsu production skills, they believe that they will be able to offer more reliable products for consumers. Third, Fujitsu will provide Cisco with a more prominent sales presence in the Japanese market. Fourth, sales may also increase by the bundling of the co-branded routers together with other telecommunication that Fujitsu offers and creating a marketing plan that provides a comprehensive solution to consumers. The alliance began offering their first products in May of 2006. Both firms benefit from the alliance.

\section{Conclusions}

As can be seen from the various cases and examples of foreign market entry, there is no right or wrong way of entering a market. Each case is unique and requires a special strategy that is completely different from any other. There is also no entry strategy that is superior to others. Each different strategy can be successful if the firm takes the time before hand to extensively research the attractiveness of possible countries, their political and economic environment, their potential for long-term growth, and the benefits and costs associated with entering any given market.

\section{References}

Gordin, A. (2011). Destination unknown, opportunity certain. Industry Week, 260(2), 52-54.

Harangus, D., \& Duda, D. D. (2009). The strategies of foreign market's penetration used by Romanian enterprises from Western five region. Proceedings from Annals of Danube Adria Association for Automation and Manufacturing (DAAAM). Hill, C. W. I. (2013). International business: Competing in the global marketplace. New York: McGraw-Hill Irwin. Porter, M. E. (1980). Competitive strategy: Techniques for analyzing industries and competitors. New York: Free Press. Root, F. (1987). Entry strategies for international markets. Lanham: Lexington Books. 